\title{
Impact of Human Capital and Innovation towards Total Factor Productivity (TFP): A Case of Manufacturing Sector in Palm Oil Industry in Malaysia
}

\author{
Naiimah Mohd Sofia ${ }^{a}$, Noorasiah Sulaiman ${ }^{\text {b }}$, Mohd Fahmy-Abdullah ${ }^{\text {c }}$, Suliadi Sufahani \\ Firdaus $^{d}$ \\ ${ }^{\mathrm{ab}}$ Faculty of Economics and Management, Universiti Kebangsaan Malaysia, 43600 UKM Bangi, Selangor Malaysia \\ ${ }^{\mathrm{c}}$ Faculty of Technology Management and Business, Universiti Tun Hussein Onn Malaysia, 86400 Parit Raja, Batu \\ Pahat, Johor, Malaysia \\ ${ }^{\mathrm{d}}$ Faculty of Applied Science and Technology, Universiti Tun Hussein Onn Malaysia, UTHM Kampus Pagoh, KM1 \\ Jalan Pagoh, 84600 Muar Johor, Malaysia \\ https://doi.org/10.35609/gcbssproceeding.2021.1 (73)
}

\begin{abstract}
Malaysian oil palm sector has contributed to the growth of gross domestic product (KDNK) by $37.9 \%$, of manpower by a total of $40 \%$, and of the total employment of agriculture sector by 22.1 million people in 2018 (DOSM, 2019). Furthermore, the exports performance shows that the palm oil production has increased from 180 thousand tons metric in 1965 to 27.86 million tons metric in 2019 (MPOB, 2019). The major importers of Malaysian palm oil include India, China, Pakistan, and the Netherlands. In 2016, India was the biggest importer (19.9\%), followed by China (10.1\%), Pakistan (6.4\%) and Netherlands (5.5\%). In addition to that, many oils are categorized according to the sources of oil and fat saturation which is produced globally (OWA, 2016). Palm oil register percent high by $28.0 \%$ compared with the oil other like oil bean soy $(24.0 \%)$, oil rapeseed $(13.0 \%)$ and spring sun $(7.0 \%)$, even more than the oils and fats from sources animals that only $25.0 \%$ only (OA, 2016). Although palm oil- based industries in Malaysia depend on inputs, especially human capital and technology to determine the overall performance and productivity, the sector is yet to use technology that depends on low-skilled workers. Thus, to improve the industries, the study was conducted to analyze the effects of the workers skills and technology on the total factor productivity (TFP).
\end{abstract}

Keywords: Human Capital, Productivity, Palm Oil, Data Envelopment Analysis, Panel Data 